\section{Anaplastic Multiple Myeloma with Multiple Genetic Anomalies}

Sir,

Anaplastic multiple myeloma (AMM) is an extremely rare morphological variant of multiple myeloma (MM) with remarkably poor prognosis. ${ }^{1}$ Morphologically, large-sized plasma-blastic cells with pleomorphic nuclei, often with multilobulation or multinucleation, are observed in $\mathrm{AMM} .{ }^{2}$ Past studies have revealed that $17 p(p 53)$ deletion and $t(4 ; 14)$ and CKS1B amplification occur more commonly in AMM than in nonanaplastic diseases; and this occurrence can lead to genetic imbalance and ultimately a more aggressive course and an unfavourable prognosis. ${ }^{3,4}$ Anaplastic morphology might be present during the initial diagnosis or might occur later during the course of the disease ${ }^{5}$. Furthermore, AMM is prevalent among young patients, who are predisposed to extramedullary lesions; and AMM is resistant to conventional chemotherapies and specific novel agents such as bortezomib, carfilzomib, and daratumumab. Moreover, anaplastic plasma cells can pose a diagnostic challenge by mimicking the dysplastic megakaryocytes. We, herein, present a case of a 75-year woman who was diagnosed with AMM with multiple genetic defects.

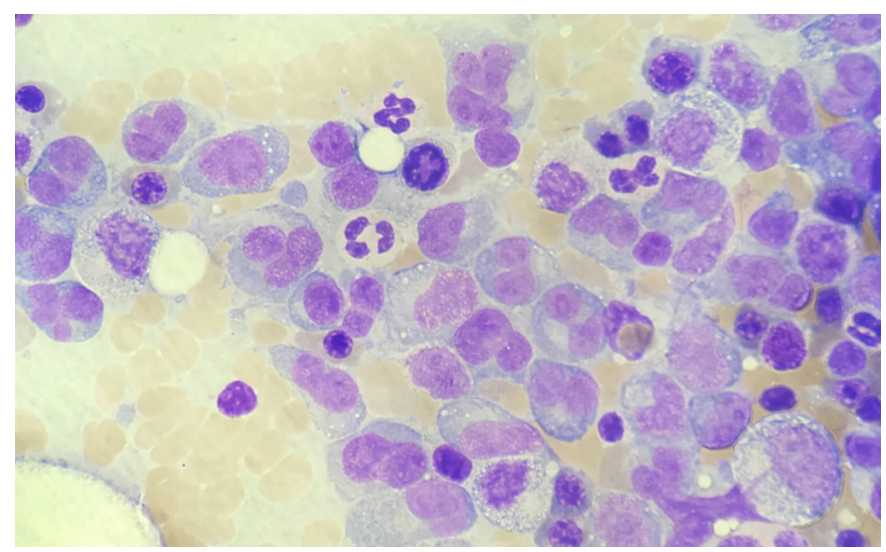

Figure 1: Mono-nuclear and bi-nucleated plasma cells in bone marrow aspiration specimen.

A 75-year woman presented with the complaint of fatigue for the past two months. Her laboratory investigations on admission revealed the following: hemoglobin $9 \mathrm{~g} / \mathrm{dL}$; leukocyte

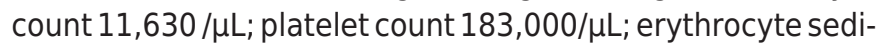
mentation rate $43 \mathrm{~mm} / 1^{\text {st }} \mathrm{h}$; creatinine $1.22 \mathrm{mg} / \mathrm{dL}$; calcium $8.72 \mathrm{mg} / \mathrm{dL}$; lactate dehydrogenase $771 \mathrm{U} / \mathrm{L}$; total protein 90.5 $\mathrm{g} / \mathrm{dL}$; albumin $39.6 \mathrm{~g} / \mathrm{L} ; \beta-2$ microglobulin $7.88 \mathrm{mg} / \mathrm{dL}$; immunoglobulin (Ig) G $33.8 \mathrm{~g} / \mathrm{L}$; IgA $0.259 \mathrm{~g} / \mathrm{L}$; IgM level $0.183 \mathrm{~g} / \mathrm{L}$; serum-free kappa chain $6.13 \mathrm{mg} / \mathrm{L}$; serum-free lambda chain $415 \mathrm{mg} / \mathrm{L}$; and kappa/lambda ratio 0.014. IgG lambda monoclonality was detected on immunoelectrophoresis of the serum sample. The presence of rouleaux formation was determined in the peripheral smear. Predominantly, bi- and tri-lobed plasma cells, comprising nearly $50 \%$ of all mononuclear cells, were recorded on bonemarrowaspiration (Figure 1). The condition was accordingly diagnosed as MM on bone marrow biopsy [lambda (+), kappa (-), CD138 (+)]. The clonal plasma cells from the bone marrow aspirate were examined by cytoplasmic interphase fluorescence in situ hybridization for myeloma-related genomic abnormalities. The positive cut-off level was established as that exceeding $5 \%$. In case of multinucleated cells, any one of the nuclei containing the fluorescence in situ hybridisation abnormality was counted as positive. We noted $35 \%$ deletion in the $13 q 14.3$ gene region, $35 \%$ deletion in the p53 gene region, $30 \%$ signals suggesting rearrangement of the IGH gene region, 35\% trisomy of arm q of chromosome 1 , and $30 \% \mathrm{t}(14-16)$ fusion during the genetic examination. Moderately diffuse and symmetrically increased fluorodeoxyglucose (FDG) uptake was observed on positron emission tomography-computed tomography (maximum standardised uptake value: 4.55-.6.26) in the axial and the appendicular skeleton in the region conforming to the bone marrow. The patient was accordingly diagnosed with $\mathrm{AMM}$, and treatment with bortezomib, cyclophosphamide, and dexamethasone was initiated. Unfortunately, the patient developed pneumonia at the end of the first cycle of the treatment and died.

\section{CONFLICT OF INTEREST:}

The authors declared no conflict of interest.

\section{AUTHORS' CONTRIBUTION:}

SD: Conception, design, manuscript writing.

AT: Materials, data collection, literature review.

OC: Manuscript writing, literature review, critical review.

\section{REFERENCES}

1. Foucar K, Raber M, Foucar E, Barlogie B, Sandler CM, Alexanian R. Anaplastic myeloma with massive extramedullary involvement. Report of two cases. Cancer 1983; 51(1):166-74. doi: 10.1002/1097-0142(19830101)51:1 $<166$ ::aid-cncr2820510132>3.0.c0;2-7.

2. Harankhedkar S, Gupta R, Rahman K. Pleomorphic multinucleated plasma cells simulating megakaryocytes in an anaplastic variant of myeloma. Turk J Haematol 2018; 35(2):150-1. doi: 10.4274/tjh.2017.0329.

3. Fujimi A, Nagamachi $Y$, Yamauchi N, Kanisawa $Y$. Morphological transformation of myeloma cells into multilobated plasma cell nuclei within 7 days in a case of secondary plasma cell leukemia that finally transformed as anaplastic myeloma. Case Rep Hematol 2017; 2017: 5758368. doi: 10.1155/2017/5758368.

4. Bahmanyar M, Qi X, Chang H. Genomic aberrations in anaplastic multiple myeloma: High frequency of 1q21(CKS1B) amplifications. Leuk Res 2013; 37(12): 1726-8. doi: 10.1016/j.leukres.2013.09.025.

5. Maslovsky I, Lugassy G, Blumental R, Ducach A, Yehuda O, Abeliovich D. Multiple chromosomal abnormalities in 
fulminant anaplastic myeloma. Clin Lab Haematol 1999;

21(3):207-10. doi: 10.1046/j.1365-2257.1999.00207.x.

Sinan Demircioglu, Atakan Tekinalp and Ozcan Ceneli

Department of Hematology, Meram Faculty of Medicine, Necmettin Erbakan University, Konya, Turkey
Correspondence to: Dr. Sinan Demircioglu, Department of Hematology, Meram Faculty of Medicine, Necmettin Erbakan University, Konya, Turkey

E-mail: sinandemircioglumd@gmail.com

Received: December 30, 2020; Revised: April 02, 2021; Accepted: April 16, 2021

DOI: https://doi.org/10.29271/jcpsp.2022.01.132 